\title{
Assessing the Reading Competence Needs of Senior High School Students in National Examination: Teachers' Perspective
}

\author{
Arie Mayang Koesoema ADHI ${ }^{1}$, Joko NURKAMTO2${ }^{2}$, Nur Arifah DRAJATI ${ }^{3}$
}

\section{ARTICLE INFO}

\section{Article History:}

Received 01.04.2019

Received in revised form

22.07.2019

Accepted

Available online 01.09.2019

\begin{abstract}
The focus of this research is to asses the Reading competence needs of senior high school students in English National Examination (ENE) based on teachers' perspective. The background in conducting this research mainly because of two things. The first one is the importance of curriculum evaluation behind the Needs Analysis itself. The second one is the importance of the certain preparation for strengthening English material to face the incoming English National Examination. Both of these backgrounds are equally important for students and teachers at once. This study is carried out with the objectives to answer the problems, that is to know what do 12 grader senior high school students' needs in order to have English Reading competence of National Examination based on teachers' perspective. The next objective is to find out what kinds of effort do teachers make to fulfil those needs. The last objective is to discover what obstacles are faced by teachers in order to fulfill those needs. All of these questions are framed within the scope of the teacher's perspective. The data of this research, included some questionnaires. This research already debriefed 5 English teachers who teach grade 12. They are from MGMP or English Teacher Forum of senior high schools in Boyolali Regency, Central Java Province, Indonesia. They were involved in filling out the questionnaire \& also interview where the results were used as the main data in this study. The final findings in this study include the fact that: (1) the basic needs of students in reading competence are the mastership in Reading comprehension, the mastery of sufficient and adequate vocabulary and also high motivation in learning, (2) the teachers then made several programs to meet the needs of the students by providing additional Reading material and adding vocabulary, implementing Computer Based National Examination Simulation, Increasing awareness and motivation of students in reading English texts, Applying group discussion and student mentoring, Inserting speaking material in Reading learning, \& making English Modules (3) students' instant habits in using gadget, the inconsistency between the compulsory in 12th grade curriculum and the material that must be taught by the teacher in the National Exam preparation class, lack of English teacher curriculum, books from the government are poor in content, low motivation \& concentration of students in English lessons in the classroom, and low vocabulary mastery of students are the main obstacles that are faced by teachers in their efforts to increase students Reading competence in ENE.
\end{abstract}

(C) IJERE. All rights reserved

Keywords:

Reading Competence, Needs Analysis, English National Examination, Teachers' Perspective.

\section{INTRODUCTION}

The focus of this research is to assess the Reading competence needs of senior high school students in English National Examination (ENE) based on teachers' perspective. The writer is interested in conducting this research mainly because of two things. The first one is the importance of curriculum evaluation behind the Needs Analysis itself (Iwai et al., 1998, p. 6). The second one is the importance of the certain teachers' preparation for strengthening English material to face the incoming English National Examination (Bahçuvanoğlu, 2017, p. 21; Furaidah, Saukah, \& Widiati, 2015, p. 36). Both of these backgrounds are equally important for students and teachers at once.

For the first reason, Needs Analysis and curriculum evaluation studies has a significant role and become very urgent since a lot of research in the world proves that some of the curriculum set by the stakeholders are not in accordance with the needs of learners. For example, a specified analysis of the students' needs in Saudi Arabia schools shows that English syllabuses ignore students' needs in many cases (Al-Hamlan \& Baniabdelrahman, 2015, p. 119). In the same year, Sahar Fadel in 2015 held a study at King Abdulazis University (KAU) and found that the new students argue that they cannot find practical benefits from the one-year General English (GE) program held by the university as a prerequisite for their faculty entry (Fadel, 2015, p. 15). A kind of research at the University of Hasanuddin also found similar inconsistencies between program makers and learners' needs. The study summarized students' suggestions

Corresponding e-mail: ari.mayang@gmail.com , English Education Department, Faculty of Teacher Training \& Education, Sebelas Maret University, Indonesia, https://orcid.org/0000-0002-4754-45881 Head of English Education Department, Faculty of Teacher Training \& Education, Sebelas Maret University, Indonesia, jokonurkamto@gmail.comhttps://orcid.org/0000-0002-8231-0779², Lecturer of English Education Department, Faculty of Teacher Training \& Education, Sebelas Maret University, Indonesia, drajatinur@gmail.comhttps://orcid.org/0000-0001-5828-51073 
Adhi,A.M.K., Nurkamto,J. \& Drajati,N.A. (2019).Assessing the reading competence needs of senior high school students in national examination: Teachers' perspective. International Journal of Educational Research Review,4(4),644-651.

that it is better that EAP course should be taught in the first semester and not in the last semester (Wahyono, 2016, p. 1011).

Needs Analysis study as a part of curriculum evaluation is important to be arranged inside the classroom (Al-Hamlan \& Baniabdelrahman, 2015, p. 118). Al-Hamlan further explained that one of the main goals of the Needs Analysis is to find the necessary remedial steps that must be taken to improve the main curriculum in the field of English language learning. This is the reason why Needs Analysis as curriculum evaluation inside the classroom is need to be conducted by teachers. For the second reason, the needs analysis study needs to be implemented on the subject of the National Exam because the exam position is quite influential for students and teachers. The National Examinations is a government test arranged to examine students' performances and competences in national scope (Nahdia, 2017, p. 93). Indonesian National Examination can be defined also as a test to measure and evaluate the students' competence nationally by the central government after the process of teaching and learning (Sukyadi \& Mardiani, 2011, p. 100).

English test such as English National Examinations (ENE) in Indonesia has become the part of English for Specific Purposes (ESP). In principle, each ESP test is classified as a performance test that aims to assess certain skills needed to succeed in language (Tratnik, 2008, p. 5). As a conclusion, English test in Indonesian National Examination may defined as an English performance test held by the central government to measure and evaluate the students' competence nationally that aims to assess certain skills needed to succeed in English language.

This exam began the first time in 1950 until now and has undergone many changes. Because the important position of the exam as one of the parameters of student graduation, the school places National Examinations in very important events, and makes schools compete to provide training and special preparation to deal with it. English as one of the subjects tested in the National Exam also received special attention, especially by teachers. English teachers must work hard to graduate students so that they can pass the test brilliantly, to achieve this, the teachers took various research and development from English language learning in the classroom. One product that can be used to prepare the condition of students who are ready to face the National Exam in English is to conduct a Needs Analysis study in the classroom. These things above make the writer interested in raising the theme of the Needs Analysis and National Examination in this study.

\section{PREVIOUS STUDIES}

Some previous studies on the theme of Reading Needs Analysis have been conducted by the experts and researchers. Sahar Fadel and Tariq Elyas in 2015 conducted a study at King Abdul Aziz University and found that the additional reading university program was still too little and the students were willing to have additional reading programs to improve their reading proficiency (Fadel \& Elyas, 2015, p. 26). Edy Wahyono \& Dewi Puspitasari in 2015 held a research to students in Hasanuddin University and found that students want to further enhance their understanding of reading lessons and want to apply several reading strategies so that their EAP learning becomes more effective and efficient (Wahyono \& Puspitasari, 2015, p. 1013). S. Salam in 2017 held a research to describe the need of development of 'Reading Comprehension' teaching materials to students and lecturers of Indonesian Language and Literature Education Department, Gorontalo State University and it is found that the Reading teaching materials used in the program not in accordance with the needs of students (Salam, 2017, p. 112). A kind of reading research of first-year students at the University of Pretoria Sociology Department by Naomi Adjoa Nana Yeboah Boakye and Magdaline Mbong Mai in 2016, found that students tended to worry about not being able to understand the reading module because the module was not offered in the home language (Boakye, 2016, p. 244).

Meanwhile in the scope of National Examinations, Nanang Zubaidi \& Budi Tiara Novitasari in 2014 conducted research from several volunteer students in Yogyakarta. The findings said several suggestions based on students' needs, namely: English National Exams must be completed with progress-based assessments; English National Examination must evaluate four students' language skills and their current language acquisition; and the English National Examination must be designed to suit the educational situation and school facilities as well as the conditions of the students themselves (Zubaidi \& Novitasari, 2014, p. 6). From the studies above, one equation was found with the research. There are four studies 
focusing on the reading Needs Analysis and one study focusing on National Examinations. However, one difference and a prospective gap was obtained from the research above, that is the previous research did not involve the teacher's point of view or teachers' perception as the subject of the study. This section also becomes the renewal factor the writer offers through this research. The significance of this research is that National Examinations in Indonesia is still a substantial topic to be discussed and is useful for implementing the results of this study for the improvement of the National Exam preparation curriculum in the following years.

\section{AIM OF THE STUDY}

Aim of this study is to answer the problems, that is to know what do 12 grader senior high school students' needs of Boyoli Regency, Central Java, Indonesia in order to have English Reading competence of National Examination based on teachers' perspective. The research took reading competence since it covers $70 \%$ of the National Examination material and is considered important to be mastered by students (Ristanto, Zubaidah, Amin, \& Rohman. 2017. p. 51). The next objective is to find out what kinds of effort do teachers make to fulfil those needs. The last objective is to discover what obstacles are faced by teachers in order to fulfill those needs. Students who were the objects in this study included male and female students. They are dominated by Javanese tribes, aged between 16 to 19 yeras old, and came from 5 public schools in Boyolali Indonesia.

\section{THEORITICAL REVIEW}

Many experts began to use Needs Analysis research as the subject of their study. They are also began to define Needs Analysis based on their respective understanding. According to Jack C. Richards (Richards, 2010, p. 51), Needs Analysis is defined as certain procedures are used to collect data and documents about the needs of students. Richards added, Needs are often described as linguistic deficiencies, that is, describing the differences between what today's learners can do in the context of their language skills and what they should be able to do (2010, p. 54). Richards also underlined, that Needs here are often explained in terms of language needs, that is, as language skills needed to survive in a society that demands a dominance or English ability (2010, p. 55).

Nunan (1994, p. 54) argues that Need analysis is a set of procedures for determining parameters or measuring instruments of a study program. J.D. Brown defined Needs Analysis (NA) as systematic collection and analysis of various subjective and objective information needed to determine and validate the objectives of a sustained curriculum that meets the requirements of student language learning in a particular institutional context that influences the learning and teaching situation (Brown, 1995, p. 36). Another researcher, Douglas Brown (2001, p. 35) defined Needs Analysis as activities that are based on gathering various kinds of information that will serve as a basis for developing a curriculum that will meet the learning needs of groups of students on certain courses. While according to Iwai et al. (1998, p. 6), Needs Analysis as the activities that are involved in collecting information that will serve as the basis for developing a curriculum that will meet the needs of a particular group of students. From the definitions above we may conclude that Needs Analysis is a set of systematic process \& activities to gather subjective and objective information to define, validate and find out the main needs of learners or groups of learners that satisfy the language learning requirements of students that will serve as the basis for developing a curriculum.

John Munby in 1978 through his book entitled "Communicative Syllabus Design, A Sociolinguistic Model for Defining the Content of Purpose Spesific Language Programmes" reminded that in the context of ESP syllabus \& material are determined in all essentials by the prior analysis of the communication needs of the learners, so that it needs to be carefully calculated and carefully, the profile of the course needs is right on target (Munby, 1978, p. 2). Jeremy David Cowling (2007) further illustrated the benefits and ultimate goals of a Needs Analysis study, that is to get deep insights and more precise input on current and future language learner needs from various perspectives, including subject teachers, students concerned and former students to assist in making appropriate decisions about goals and objectives that must be appreciated by the new curriculum and to ensure that curriculum content fits the needs of students as closely as possible. Nunan and Lamb (1996, p. 27) stated, Needs Analysis establish a foundation to 
Adhi,A.M.K., Nurkamto,J. \& Drajati,N.A. (2019).Assessing the reading competence needs of senior high school students in national examination: Teachers' perspective. International Journal of Educational Research Review,4(4),644-651.

determine the direction and purpose of a course In the context of National Examinations, a comprehensive needs analysis is needed, so that teachers can determine the appropriate and suitable course design in their classroom.

\section{METHOD}

The research was conducted in MGMP or English Teacher Forum of senior high schools in Boyolali Regency, Central Java. This English MGMP is a forum consisting of English language teachers from public high schools in Boyolali district. This forum is an official monthly forum held under the supervision of the Central Java Provincial Education Office. This district level forum is led by a chairperson, who is responsible for ensuring the holding of this forum meeting activities every month. The things that are widely discussed in this forum include making questions for mid semester, semester, and USBN examinations. The venue for the MGMP forum meeting took turns from one high school to another.

This research used survey \& interview to teachers as the method of study. In this research, the author interviewed 5 respondents as the subject of study. They are five English teachers, consisted of 3 male teachers and 2 female teachers, aged between 37 to 50 years old members of the English MGMP in Boyolali Regency, Central Java. All of them were Javanese, each having 8 to 20 years of teaching experience and all were from public schools in Boyolali Indonesia.

\section{DATA ANALYSES}

The research design that applied in this study is to use the Case Study approach. In accordance with what Yin said (2003, p. 13) Case Study research is an investigation based on direct field experience. This kind of research will investigate current events within the scope of daily life by processing the sources of information obtained. In this case, the researcher collected an analysis of student needs of reading skill to deal with ENE. This study examined the Needs Analysis study through the perspective of the teachers as a figure who are directly involved in implementing ENE preparation at schools.

Yin (2003, p. 85) also presents there are six sources of evidence or data sources commonly used by researchers. Data sources include documentation, archive records, interviews, direct observation, participant observation, and physical artifacts. Meanwhile, in this study, the data sources that are processed and used include: documentation, archive records, interviews, and direct observation.

According to Yin (2011, p. 129) in qualitative research, authentic data sources may be obtained from several things, namely: interviewing, observing, collecting and examining (material) and feeling. In conducting interviews, researchers applied interviews to obtain facts about the topic surrounding ENE preparation and their opinions on the exam. Second, direct observation was conducted at MGMP meetings to see and summarize the strategies of the teachers in preparing their students to face ENE. Meanwhile, at the stage of material collection, various types of artifacts were collected to complete the research data. this data can consist of learning documents, syllabus, teacher learning plans, and daily teaching journals.

There are three general analytic strategies proposed by Yin (2003, p. 111). They are: leaning on theoretical propositions, thinking of rival explanations, and developing case descriptions. Meanwhile in this study the method of developing a case description was a strategy chosen by the researcher. It is to develop a descriptive framework for organising the case study (Yin, 2003: 114). This study developed a description of the case for 12th grade reading needs analysis in the National Examination in Boyolali Regency.

Yin (2003, p. 109) also has well described five techniques for analyzing data, namely: pattern matching, linking data with propositions, developing explanations, time series analysis, and cross-case synthesis. For the type of descriptive case study, a suitable strategy for analyzing data is by using a pattern matching strategy (Yin, 2003, p. 116). According to Yin, rival explanations as patterns are a suitable type of this pattern matching strategy in this single case study (Yin, 2003, p. 119). The competitor's explanation includes an analysis that explains the evidence in the field. Matching here is analyzing data based on patterns to explain data from the field.

\section{FINDINGS}

In survey, questionnaire questions were conceded on 3 core questions that were expected to answer students' needs for Reading's competence to face the English National Examination. On this survey, the 
Adhi,A.M.K., Nurkamto,J. \& Drajati,N.A. (2019).Assessing the reading competence needs of senior high school students in national examination: Teachers' perspective. International Journal of Educational Research Review,4(4),644-651.

researcher has asked the teachers to fill out 3 questionnaires about the students' needs in Boyolali regarding the English National Examination (ENE).

The list of questions submitted to the teachers included:

1. What do 12 grader senior high school students' needs in order to have English Reading competence of National Examination based on teachers' perspective?

2. What kinds of effort do teachers make to fulfil those needs?

3. What obstacles are faced by teachers in order to fulfill those needs?

This study is a study of need analysis of students' needs regarding Reading competence in the English National Examination. The author has interviewed five teacher respondents regarding the needs of these students. From the contents of the interview above, the writer can synthesize that out of the five respondents interviewed, data obtained from respondent 1 states that there are 2 aspects of the students' basic needs to fulfill reading competencies in the English National Examination, namely Reading skills and vocabulary. Meanwhile respondent 2 stated that there were 3 aspects of student needs, namely mastery of reading material, mastery of vocabulary, and student learning awareness. Respondent 3 states that there are 3 aspects of student needs, namely understanding the reading material, vocabulary mastery, and student learning motivation. Respondent 4 gave a simpler statement stating that there was only one aspect of students' reading needs, namely mastery of vocabulary. The last respondent namely teacher 5 stated that there were 3 Reading needs of students in the National Examination namely material understanding, mastery of vocabulary and student learning motivation. From the 5 respondents' opinion the intersection data was obtained, that the most important aspects that become the Reading needs of students for the English National Examination is the vocabulary mastery.

In the second interview question was related to the efforts of the teachers to improve students' competency in reading the National Examination, the respondents gave the following answers, respondent 1 answered there were 2 teacher businesses namely by providing English language compaction programs and conducting Computer-Based National Exams simulation. Respondent 2 gave an answer that there was 1 teacher's effort that was done to improve students' reading competencies, namely the improvement of Reading material as well as vocabulary. The third respondent gave answers to 4 types of businesses that the teacher carried out in improving students' reading competencies, namely increasing vocabulary, increasing learning motivation, activating student mentoring, and inserting speaking learning. The fourth respondent stated that there was one main effort of the teacher in improving Reading competence of students, namely making student learning modules. The last respondent or teacher 5 stated that there were 2 teacher efforts to improve Reading students' competencies, namely giving additional reading and vocabulary materials and running student discussion groups. From the interview data above, intersection data shows that the teacher's effort to improve Reading competence of students in the English National Examination is mainly in providing additional Reading material and adding vocabulary.

In interviews for the third or final question, interview data was obtained that the teachers found several obstacles in their efforts to improve students' competence in reading the National Examination. Respondent 1 stated that there were 4 obstacles that made it difficult for teachers in the Reading learning class, namely the habits of students who were addicted to gadgets, the 2013 curriculum did not provide a special space for vocabulary strengthening, the English teacher teaching hours were reduced by 50\%, not quality books from the government. The second respondent gave two types of obstacles experienced by the teacher, namely the lack of teaching hours of English teachers and the low motivation of student learning, the third respondent gave the results of interviews, there were 2 types of obstacles faced by teachers namely low student motivation and low mastery of vocabulary. The fourth respondent admitted that there was one obstacle that the teacher encountered, it was the incompatibility of the curriculum with the National Exam preparation material. The last respondent stated that low student motivation was the main obstacle felt by the teacher in learning. From the interview data above the authors get data intersection that low motivation \& concentration of students in English lessons in the classroom is the main obstacle faced by teachers in their activities to increase student competency. 


\section{DISCUSSION AND SUGGESTIONS}

This paper has taken the findings that mastery of vocabulary is a key word in mastering Reading competence in relation to the National Examination. This finding is in line with the research conducted by Muharni (2017) that vocabulary mastery has a very high correlation with Reading comprehension. Alqahtani (2015) also mentioned that mastery of vocabulary is very important in Reading Comprehension. Alqahtani from King Khaled Academy, Saudi Arabia in 2015 published an article entitled "The Importance of Vocabulary in Language Learning and the Way to Teach". His research attempts to reveal whether vocabulary learning is an important part of foreign language learning. Alqahtani said that research has shown that both languages are very dependent on vocabulary knowledge and the lack of knowledge and the biggest obstacle for readers to overcome and vocabulary has been recognized as the single largest source of L2 student problems (Alqahtani, 2015: 22-23).

Vocabulary mastery becomes the most Reading need for students in the English National Examination. It means that in reading competence especially for the National Examination become the main particular concern from teachers and students. With good reading skills and honed early on, students are expected to be better prepared when facing Reading questions on the National Examination. The teacher certainly must think of more effective ways so that students can have this Reading Comprehension competency. Meanwhile, students' reading ability is one indicator of their success is the mastery of good vocabulary. With a lot of \& sufficient vocabulary, of course students have no difficulty when understanding English questions or texts on the National Examination. The teacher needs to think about the right method so that students can have a lot of memorized vocabulary. On the other hand, external effort is not enough, students must have an internal drive, namely high learning motivation. Because of course it will not be optimal when the teacher has tried to improve students' abilities, but the students themselves are not enthusiastic in learning. The motivation of these students themselves can be stimulated through interesting and fun learning methods by the teacher. This study also found that there is 1 thing that the teacher could do in activities to achieve Reading students' competencies, namely: providing additional Reading material and adding vocabulary. Teachers can implement this finding through the MGMP at the school or at the city / regency level or through the optimization of the development of syllabus and lesson plans or learning tools that are the handbook for each teacher. With the discovery of obstacle that have the potential to arise in teacher teaching activities in the classroom, the teacher needs to anticipate the following in order to get a solution immediately, namely the low motivation \& concentration of students in English lessons in the classroom. By giving early attention to the potential of the above disturbances, it is expected that the teacher does not get a significant obstacle in his efforts to achieve the best competencies for his students in the Reading Examination National skill.

Vocabulary mastery plays an important role in Reading language skills in particular and it should be agreed that mastery of vocabulary is one of the most important components of language acquisition. Furthermore as the results of this study which found that strengthening vocabulary is the most important supporting element of mastery of Reading, it becomes necessary to pay attention for the teachers especially the 12th grade teachers to focus more on strengthening vocabulary so that students are better prepared to face ENE. The teacher can enter deepening vocabulary activities into the lesson plan to increase students' Reading competence so they are better prepared to face the Reading National Examination. Teachers also can use more varied learning methods so that they can increase student learning motivation. While With a $70 \%$ proportion of the National Examination in the form of Reading, it is expected that students prepare themselves better in the Reading Comprehension competency. Students hopefully are more serious in learning and trying optimally so that the motivation to learn English is maintained to the maximum. For other researchers who will develop this study, this research can be a starting point for broadening more comprehensive research. Other researchers who found deficiencies in this study could make improvement research that is expected to make similar research in the field of National Examination even more complete. 


\section{REFERENCES}

Al-Hamlan, S. \& Baniabdelrahman, A., A. (2015). A needs analysis approach to efl syllabus development for second grade students in secondary education in Saudi Arabia: A descriptive analytical approach to students' needs. American International Journal of Contemporary Research Vol. 5, No. 1, February 2015, 118-145.

Bahçuvanoğlu, F., F. (2017). Evaluation of teachers ' views concerning 1deality levels. IJERE, International Journal of Education Research Review, 3 (1), 21.

Boakye, N., A., N., Y., \& Mai, M., M. (2016). A needs analysis for a discipline-specific reading intervention. Canadian Center of Science and Education. English Language Teaching Vol. 9, No. 3; 2016 ISSN 19164742 E-ISSN 1916-4750. ISSN 1916-4742 E-ISSN 1916-4750.

Brown, H. D. (2001). Teaching by principles: An interactive approach to language pedagogy. New York: Addison Wesley Longman.

Brown, J. D. (1995). The elements of language curriculum: A systematic approach to program development. Boston: Heinle and Heinle.

Cowling, J. D. (2007). Needs analysis: Planning a syllabus for a series of intensive workplace courses at a leading Japanese company. English for Specific Purposes, 26, 426-442.

Fadel, S., \& Elyas, T. (2015). ESP needs analysis to integrate a scientific reading program in the English language institute at King AbdulAziz University. International Journal of Educational Investigations. Vol.2, No.4, 2015 (April), 14-27.

Iwai, T., Kondo, K., Limm, S. J. D., Ray, E. G., Shimizu, H., and Brown, J. D. (1999). Japanese language needs analysis. Available at: http://www.nflrc.hawaii.edu/Networks/NW13/NW13.pdf

Muharni. (2017). The influence of grammar and vocabulay mastery on students' reading comprehension at language development center of UIN SUSKA Riau. J-SHMIC, Journal of English as Academic. DOI: https://doi.org/10.25299/jshmic.2017.vol4(1). 508.

Nahdia, K. (2017). Washback analysis of students' perception and teachers' teaching material of english national examination. Journal of English Language Teaching. ELT FORUM 6 (1) (2017), 92-101. http://journal.unnes.ac.id/sju/index.php/elt.

Nunan, D. (1994). The learner-centered curriculum. Cambridge: Cambridge University Press.

Nunan, D. and Lamb, C. (1996). The self-directed teacher. Cambridge: Cambridge University Press.

Richards, J., C. (2010). Curriculum development in language teaching. Cambridge: Cambridge University Press.

Ristanto, R., H., Zubaidah, S., Amin, M., \& Rohman, F. (2017). the potential of cooperative integrated reading and composition in biology learning at higher education. IJERE, International Journal of Education Research Review, 3 (1), 51.

Salam, S. (2017). Developing needs analysis based-reading comprehension learning materials: A study on the Indonesian language study program students. Australian International Academic Centre PTY.LTD.

http://dx.doi.org/10.7575/aiac.alls.v.8n.4p.105

Sukyadi, D., \& Mardiani, R. (2011). The Washback effect of the English national examination (ENE) on english teachers' classroom teaching and students' learning. Kata, volume 13, Number 1, June 2011: 96-111.

Tratnik, A. (2008). Key issues in testing english for specific purposes. Scripta Manent 4 (1). 3-13.

Wahyono, E., \& Puspitasari, D. (2016). Students' Need analysis of english reading skills for academic purposes. Prosiding ICTTE FKIP UNS, 2015, Vol 1, No 1, January 2016. 
Adhi,A.M.K., Nurkamto,J. \& Drajati,N.A. (2019).Assessing the reading competence needs of senior high school students in national examination: Teachers' perspective. International Journal of Educational Research Review,4(4),644-651.

Yin, K., R. (2003). Case study research - design \& methods, Third edition. London: Sage Publication. Volume 5.

Yin, K., R. (2011). Qualitative research from start to finish. New york: The Guilford Press.

Zubaidi, N., \& Novitasari, B., T. (2014). Ideal vs practice of indonesian senior high school national exam of English subject: Students' perception. Conference Paper. June 2014. https://www.researchgate.net/publication/263393377. 